\author{
LokMan Sung, ${ }^{1,2}$ M.D.; Kilak Kesha, ${ }^{3}$ M.D.; Jeffrey Hudson, ${ }^{4,5}$ M.D.; Kelly Root, ${ }^{1}$ and \\ Leigh Hlavaty, ${ }^{1,2}$ M.D.
}

\title{
Morphology of Modern Arrowhead Tips on Human Skin Analog*
}

\begin{abstract}
Archery has experienced a recent resurgence in participation and has seen increases in archery range attendance and in children and young adults seeking archery lessons. Popular literature and movies prominently feature protagonists well versed in this form of weaponry. Periodic homicide cases in the United States involving bows are reported, and despite this and the current interest in the field, there are no manuscripts published on a large series of arrow wounds. This experiment utilizes a broad selection of modern arrowheads to create wounds for comparison. While general appearances mimicked the arrowhead shape, details such as the presence of abrasions were greatly influenced by the design of the arrowhead tip. Additionally, in the absence of projectiles or available history, arrowhead injuries can mimic other instruments causing penetrating wounds. A published resource on arrowhead injuries would allow differentiation of causes of injury by forensic scientists.
\end{abstract}

KEYWORDS: forensic science, forensic pathology, compound bow, arrow, broadhead, morphology

Archery, defined as the art, practice, and skill of shooting arrows with a bow, is indelibly entwined in human history. Accounts of the bow and arrow can be chronicled throughout human civilization from its origins as a primary hunting tool, migration to utilization in combat, and to its ancient and current day use in competitive sport and recreational activities. As depicted in Paleolithic and early Mesolithic hieroglyphs, the bow is one of the world's oldest weapons (1). While people around the world employed these implements, they have all but been rendered obsolete in contemporary warfare by the advancement of firearms (2).

Despite its ancient pedigree in weaponry and sport, little documentation on arrowhead injuries in forensic literature exists. In current society, very few instances of homicides involve the bow and arrow, and when the arrow remains within the body, doubt as to the weapon used is eliminated (3). However, many modern compound bows are able to propel arrows with sufficient velocity and energy needed to pass completely through a game animal's body with ease (4) and they would likely behave similarly in humans. In these instances, those who are unfamiliar with the configuration of modern arrowheads have few published resources from which to draw.

\footnotetext{
${ }^{1}$ Wayne County Medical Examiner's Office, 1300 E. Warren Ave., Detroit, MI, 48207.

${ }^{2}$ Department of Pathology, University of Michigan, 1500 E. Medical Center Drive, Ann Arbor, MI, 48109.

${ }^{3}$ Department of Forensic Pathology, National Forensic Pathology Service of New Zealand, Auckland, New Zealand.

${ }^{4}$ Lucas County Coroner's Office, Toledo, OH.

${ }^{5}$ Department of Pathology, University of Toledo Health Sciences Campus, 2280 Dowling Hall, MS 1090, Toledo, OH, 43614.

*Supported by a grant from the University of Michigan, Department of Pathology AP Project Funding Committee Project \#64.

Received 5 Dec. 2016; and in revised form 5 Jan. 2017; accepted 6 Mar. 2017.
}

While investigations into the penetrating ability of arrows have been published (5), this article is the first large-scale study evaluating the cutaneous morphology of modern broadhead arrow tip injuries in a controlled environment. It will service as a reference and primer for medical examiners and coroners to formulate their opinions and lend support in trial.

\section{Materials and Methods}

Broadheads are arrowheads that have sharpened edges or blades used for incising tissue. Terms used in this article to describe the characteristics of the broadheads include the tip, blade, width, and grains. The tip refers the very end of the broadhead and is the first portion that contacts the target. Arrowhead blades are their cutting edges. The width describes the maximum spread or separation of the blades from one another. Grains are used to measure the mass of the broadhead, and one grain is nearly $64.8 \mathrm{mg}$.

There are multiple methods of organizing arrowheads (Table 1). One method of categorization is by having one group consisting of cutting blades that are fixed or nonmoving and a second group with mechanical blades where the cutting edges deploy upon striking or entering the target (Fig. 1). A second system of division is according to the number of major blades the arrowhead contains.

In this study, the selection of arrowheads included one field point (Fig. 2), 12 commonly used broadheads, and six variantdesign broadhead arrowheads. The two-blade broadheads included the Carbon Express ${ }^{\circledR}$ Nativ $^{\mathrm{TM}}$, Magnus ${ }^{\circledR}$ Stinger $^{\mathrm{TM}} 2$ blade, G5 ${ }^{\circledR}$ Havoc $^{\mathrm{TM}}$, Rage ${ }^{\circledR}$ X-Treme ${ }^{\mathrm{TM}}$, and the Swhacker ${ }^{\circledR}$ (Figs 3 and 4). Standard three-blade broadhead arrowheads were the G5 ${ }^{\circledR}$ Montec $^{\mathrm{TM}}$, Muzzy ${ }^{\circledR} \operatorname{Trocar}^{\mathrm{TM}}$, Rage ${ }^{\circledR}$ Kore $^{\mathrm{TM}}$, Spitfire ${ }^{\circledR}$ $\operatorname{Maxx}^{\mathrm{TM}}, \mathrm{G} 5{ }^{\circledR} \mathrm{T}^{\mathrm{TM}}$, and the Grim Reaper ${ }^{\circledR}$ Razortip ${ }^{\mathrm{TM}}$ (Figs 5 and 6). The Magnus ${ }^{\circledR}$ Stinger Buzzcut ${ }^{\mathrm{TM}} 4$ blade was the only 
TABLE 1-Arrowhead summary.

\begin{tabular}{|c|c|c|c|}
\hline \multirow[b]{2}{*}{ Brand } & \multirow[b]{2}{*}{ Model } & \multicolumn{2}{|c|}{ Blades } \\
\hline & & Number & $\begin{array}{l}\text { Fixed or } \\
\text { Mechanical }\end{array}$ \\
\hline Allen & Field point & None & \\
\hline Carbon Express ${ }^{\circledR}$ & Nativ $^{\mathrm{TM}}$ & 2 & Fixed \\
\hline Magnus ${ }^{\circledR}$ & Stinger $^{\mathrm{TM}}$ & 2 & Fixed \\
\hline G5® & Havoc $^{\mathrm{TM}}$ & 2 & Mechanical \\
\hline Rage ${ }^{\circledR}$ & $\mathrm{X}$-Treme $\mathrm{e}^{\mathrm{TM}}$ & 2 & Mechanical \\
\hline Swhacker ${ }^{\circledR}$ & & 2 & Mechanical \\
\hline G5® & Montec $^{\mathrm{TM}}$ & 3 & Fixed \\
\hline Muzzy® & Trocar $^{\mathrm{TM}}$ & 3 & Fixed \\
\hline Rage $\AA$ & Kore $^{\mathrm{TM}}$ & 3 & Mechanical \\
\hline Spitfire ${ }^{\circledR}$ & $\operatorname{Maxx}^{\mathrm{TM}}$ & 3 & Mechanical \\
\hline G5® & $\mathrm{T} 3^{\mathrm{TM}}$ & 3 & Mechanical \\
\hline Grim Reaper® & Razortip $^{\mathrm{TM}}$ & 3 & Mechanical \\
\hline Magnus ${ }^{\circledR}$ & Stinger Buzzcut ${ }^{\mathrm{TM}}$ & 4 & Fixed \\
\hline Flying Arrow Archery ${ }^{\circledR}$ & Cyclone $^{\mathrm{TM}}$ & 3 & Fixed \\
\hline Flying Arrow Archery ${ }^{\circledR}$ & Toxic $^{\mathrm{TM}}$ & 3 & Fixed \\
\hline Outdoor Sports Products ${ }^{\circledR}$ & SaberMaxx ${ }^{\mathrm{TM}}$ & & Fixed \\
\hline Muzzy® ${ }^{\circledR}$ & Small game point & None & \\
\hline Flying Arrow Archery® & Cyclone $^{\mathrm{TM}}$ & 3 & Fixed \\
\hline Trophy Ridge ${ }^{\circledR}$ & Buckblaster $^{\mathrm{TM}}$ & 6 & $\begin{array}{l}\text { Fixed and } \\
\text { Mechanical }\end{array}$ \\
\hline
\end{tabular}

four-blade broadhead tested (Fig. 7). Variant broadheads included the Flying Arrow Archery ${ }^{\circledR}$ Cyclone $^{\mathrm{TM}}$, Flying Arrow Archery ${ }^{\circledR}$ Toxic $^{\mathrm{TM}}$, Flying Arrow Archery ${ }^{\circledR}$ Tom Bomb ${ }^{\mathrm{TM}}$, Outdoor Sports Products ${ }^{\circledR}$ SaberMaxx ${ }^{\mathrm{TM}}$, Muzzy ${ }^{\circledR}$ small game point, and the Trophy Ridge ${ }^{\circledR}$ Buckblaster $^{\mathrm{TM}}$ (Figs 8 and 9). Except for the 125 grain Trophy Ridge ${ }^{\circledR}$ Buckblaster $^{\mathrm{TM}}$, all arrowheads used were 100 grains. The arrow tips were attached to $68.6 \mathrm{~cm}$ (27-inch) Beman $\mathrm{ICS} \AA$ Bowhunter ${ }^{\mathrm{TM}}$ arrows, each with a spine stiffness of 400 and weighing 8.4 grains per inch. A Mission ${ }^{\circledR}$ Ballistic $^{\mathrm{TM}}$ compound bow with a $72.4 \mathrm{~cm}(28.5$ inch) draw length set to a $27.2 \mathrm{~kg}(60 \mathrm{lb})$ draw weight was used to fire the arrows (Fig. 10). This configuration produced an average of velocity of $86 \mathrm{~m} / \mathrm{s}(282 \mathrm{ft} / \mathrm{s})$.

The arrows were fired perpendicularly at pig carcasses from a distance of 10 meters. Previous research groups have shown the

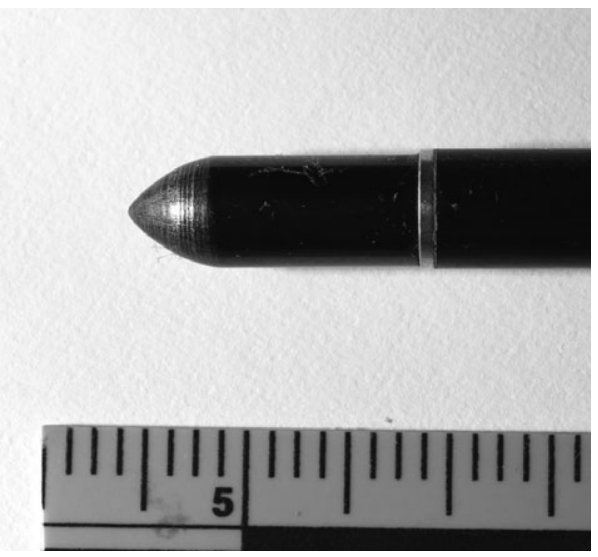

FIG. 2-Field point arrowhead. Scale in inches.

similarities of porcine skin to human skin in relation to their anatomic, physiologic, histologic, histochemical, and immunohistochemical properties (6). With these parallels, it was determined that slaughtered pigs would serve as an appropriate human ana$\log$. The carcasses were suspended from a metal frame by the legs to present the full lateral side of the animal for maximization of usable body surface area. Four Block ${ }^{\circledR}$ Classic $18^{\mathrm{TM}}$ archery targets were stacked to capture arrows that passed through the animals. Arrows that missed the animal or archery targets would fragment upon impact with a concrete barrier and then be captured by a B.U.P. Sports ${ }^{\circledR}$ The Shield $^{\mathrm{TM}}$ backstop (Fig. 11).

A Nikon D90 digital camera affixed with an AF Zoom-NIKKOR 24-85 mm f/2.8-4D IF lens was used to document the morphology of the resulting entrance wounds.

\section{Results}

The fixed, two-blade arrowheads, such as the Carbon Express ${ }^{\circledR}$ Nativ $^{\mathrm{TM}}$ and Magnus ${ }^{\circledR}$ Stinger $^{\mathrm{TM}} 2$ blade, created entrance wounds having the appearance of a typical stab wound

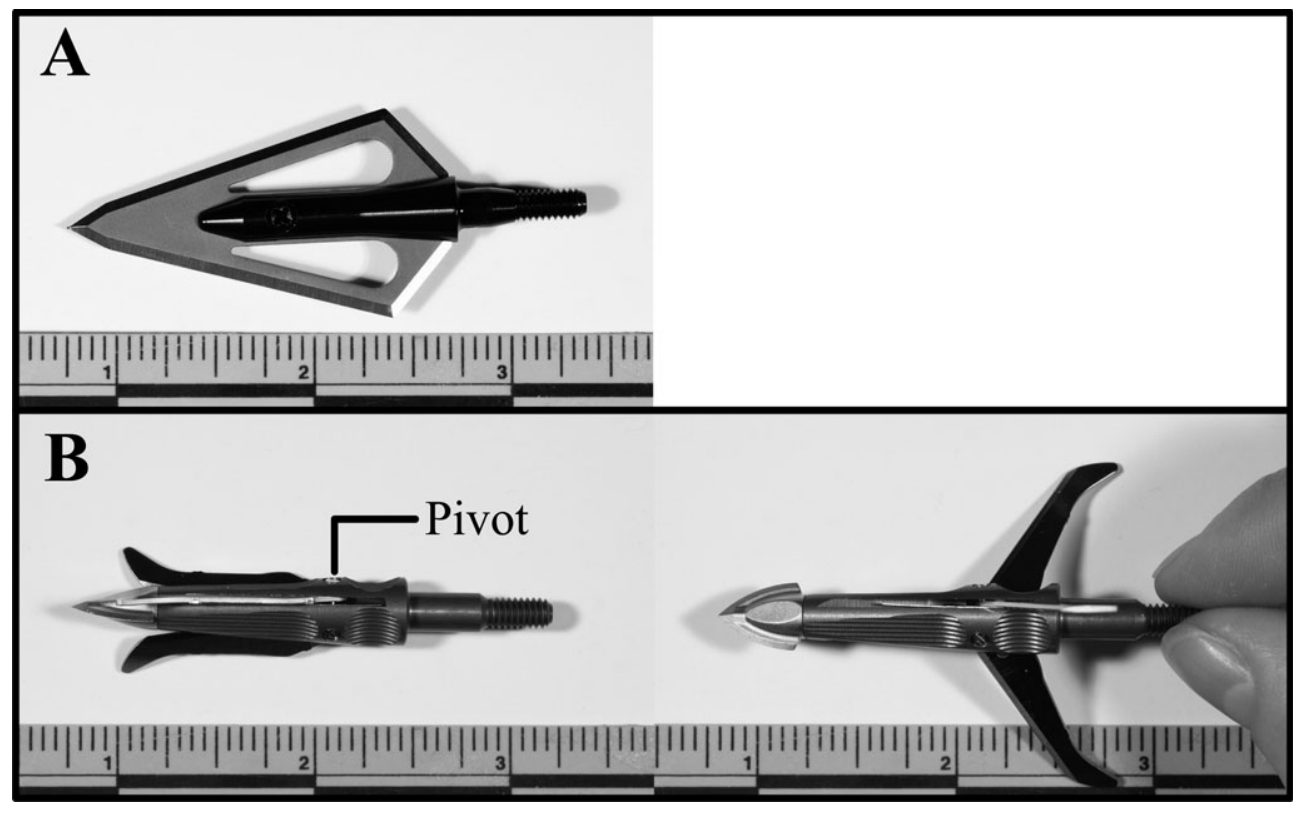

FIG. 1-Broadhead design: (A) Fixed blade (B) Mechanical. Scale in inches. 


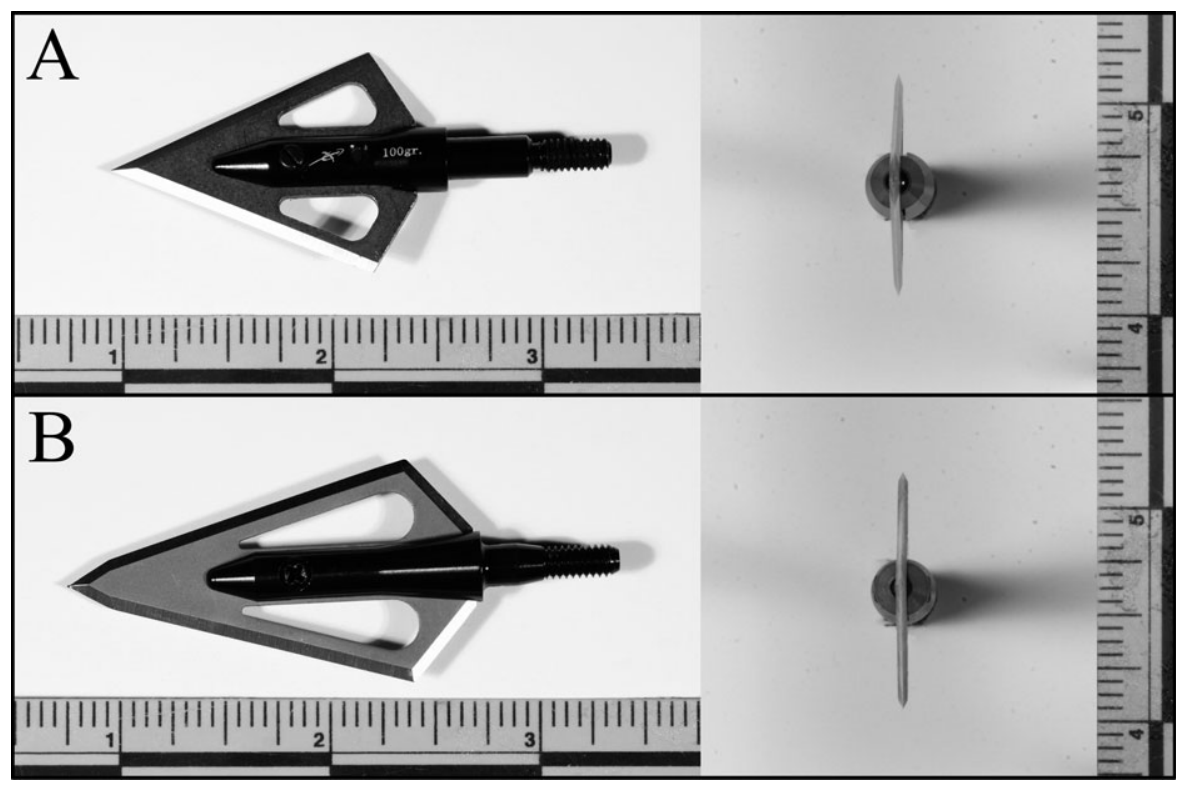

FIG. 3-Fixed two-blade broadheads, side and tip views: (A) Carbon Express ${ }^{\circledR}$ Nativ $^{T M}$ (B) Magnus ${ }^{\circledR}$ Stinger $^{T M} 2$ blade. Scale in inches.

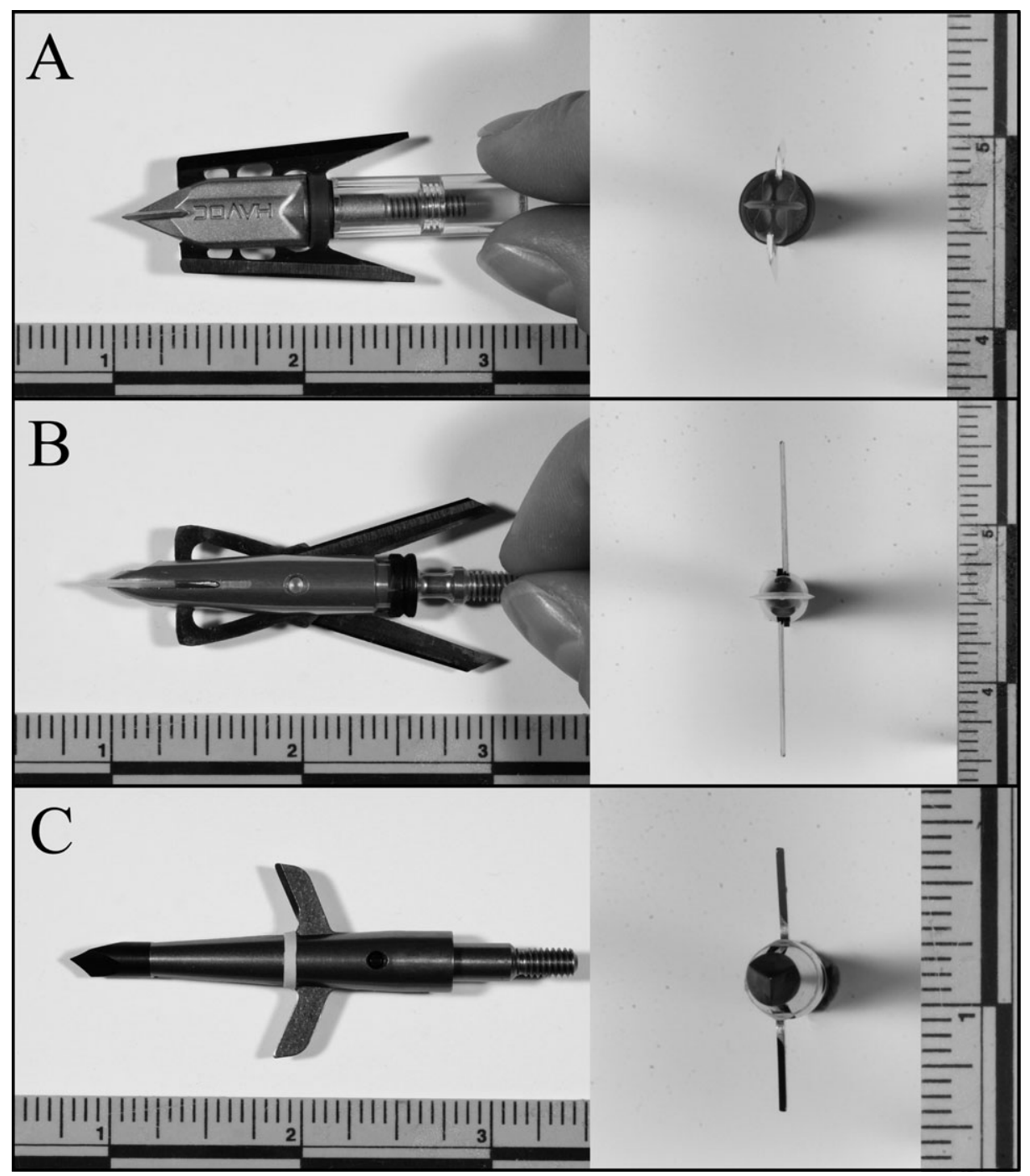

FIG. 4-Mechanical two-blade broadheads, side and tip views: (A) G5® $\operatorname{Havoc}^{T M}$ (B) Rage ${ }^{\circledR} X$-Treme $e^{T M}$ (C) Swhacker ${ }^{\circledR}$. Scale in inches. 


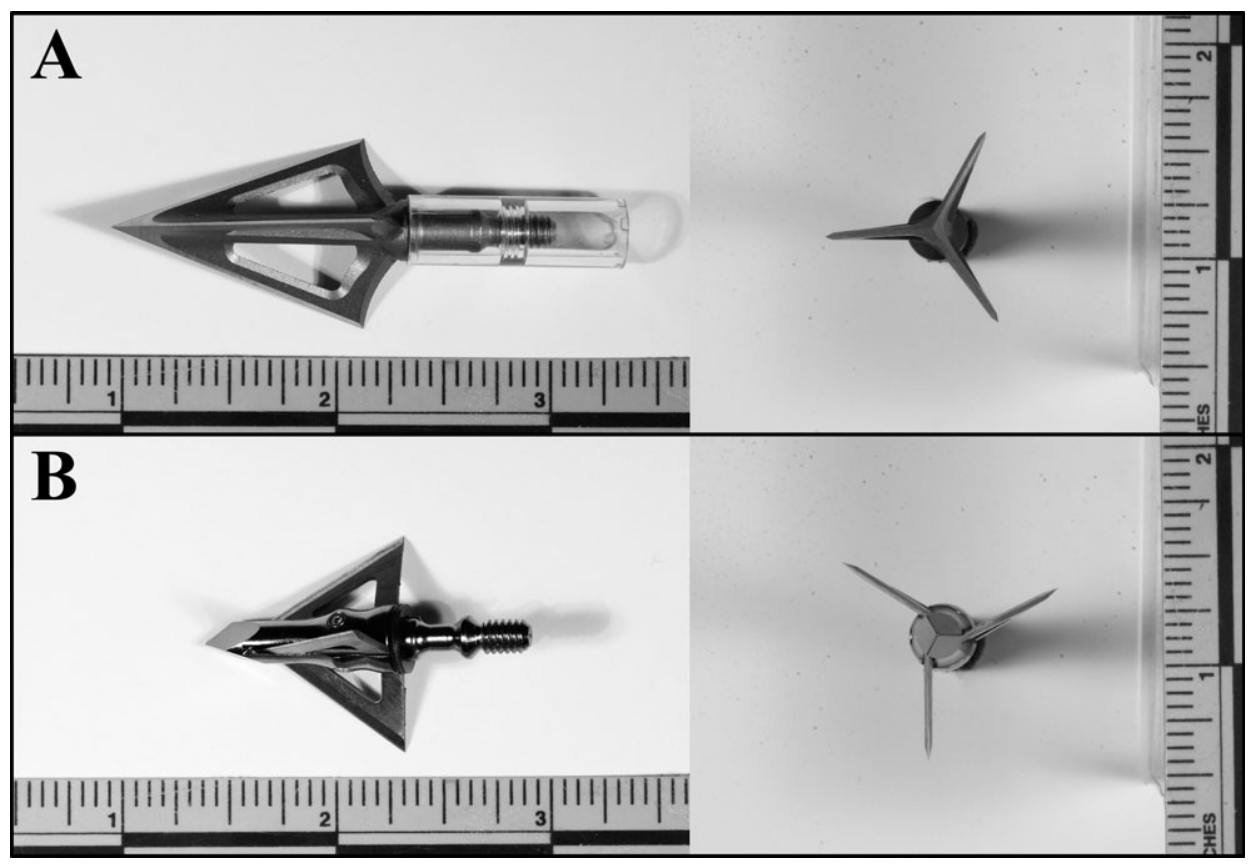

FIG. 5-Fixed three-blade broadheads, side and tip views: (A) G5® Montec $^{T M}$ (B) Muzzy® ${ }^{\circledR}$ Trocar ${ }^{T M}$. Scale in inches.

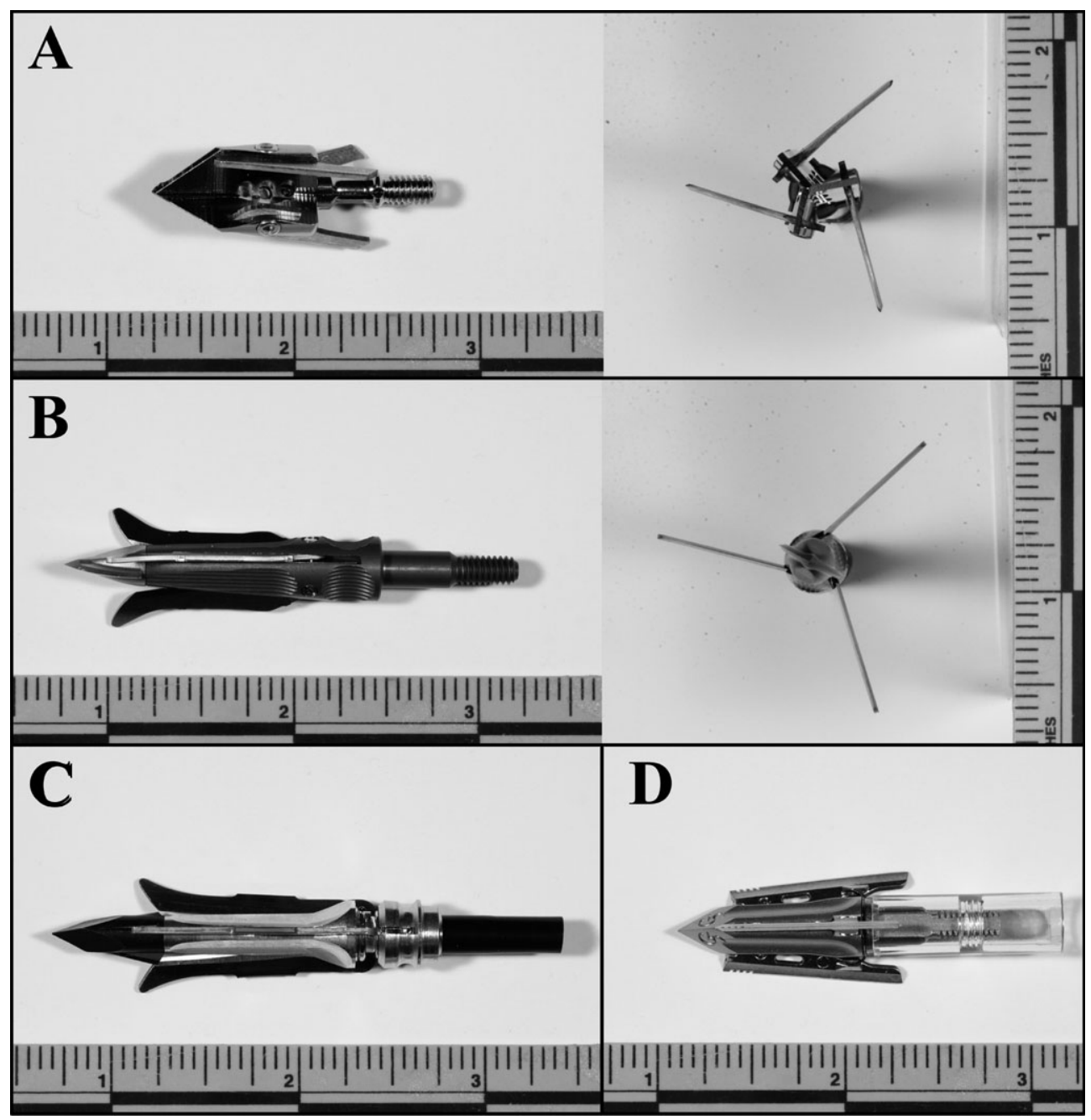

FIG. 6-Mechanical three-blade broadheads, side and tip views: (A) Rage ${ }^{\circledR} \operatorname{Kore}^{T M}$ (B) Spitfire ${ }^{\circledR}$ Maxx ${ }^{T M}$ (C) Grim Reaper ${ }^{\circledR} \operatorname{Razortip}^{T M}$ (D) G5 ${ }^{\circledR}$ T3 $^{T M}$. Scale in inches. 


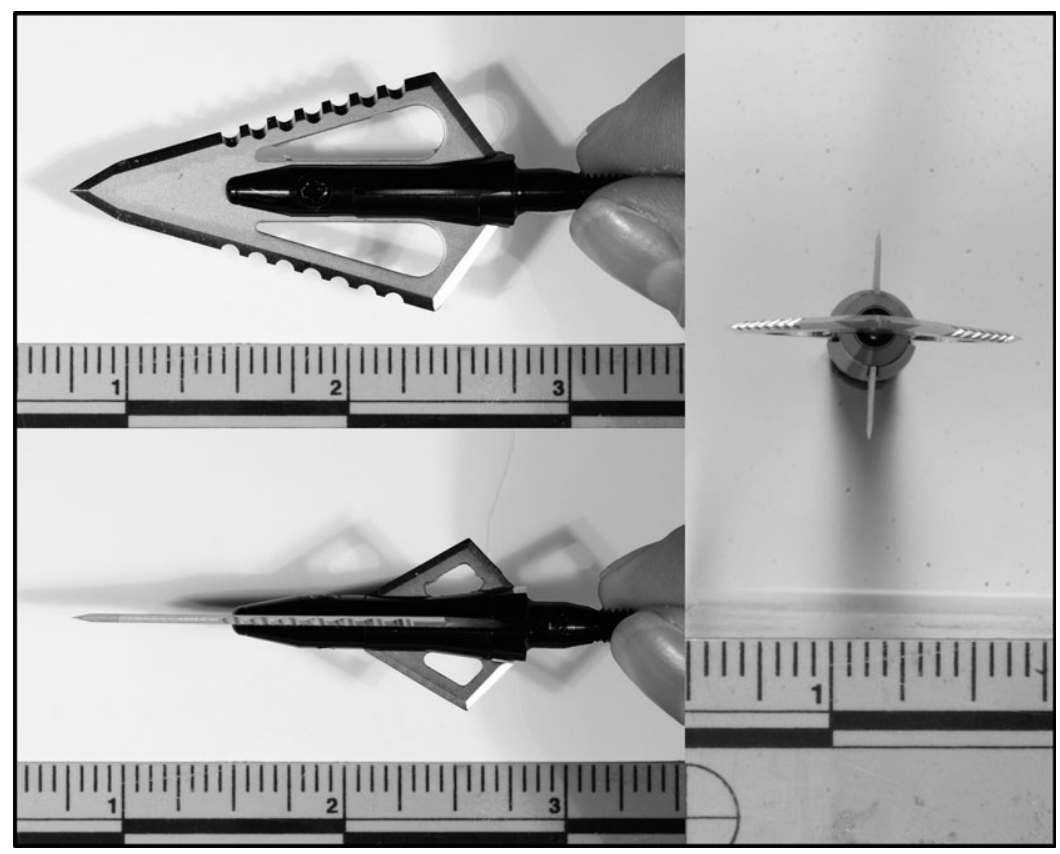

FIG. 7-Four-blade, Magnus ${ }^{\circledR}$ Stinger Buzzcut ${ }^{\text {TM }}$ broadhead, side and tip views. Scale in inches

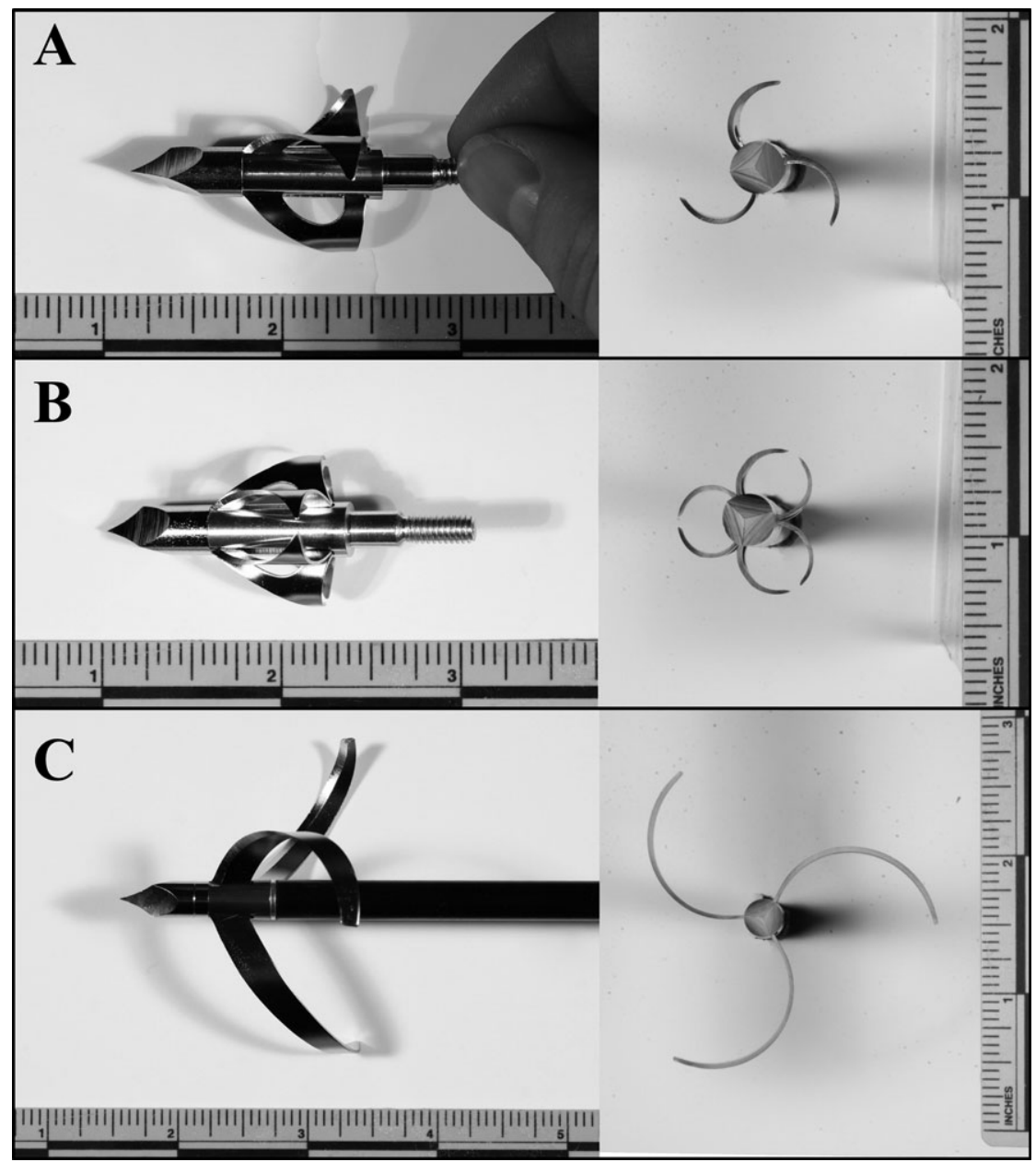

FIG. 8-Flying Arrow Archery variant broadheads, side and tip views: (A) Cyclone ${ }^{T M}$ (B) Toxic ${ }^{T M}$ (C) Tom Bomb ${ }^{T M}$. Scale in inches. 


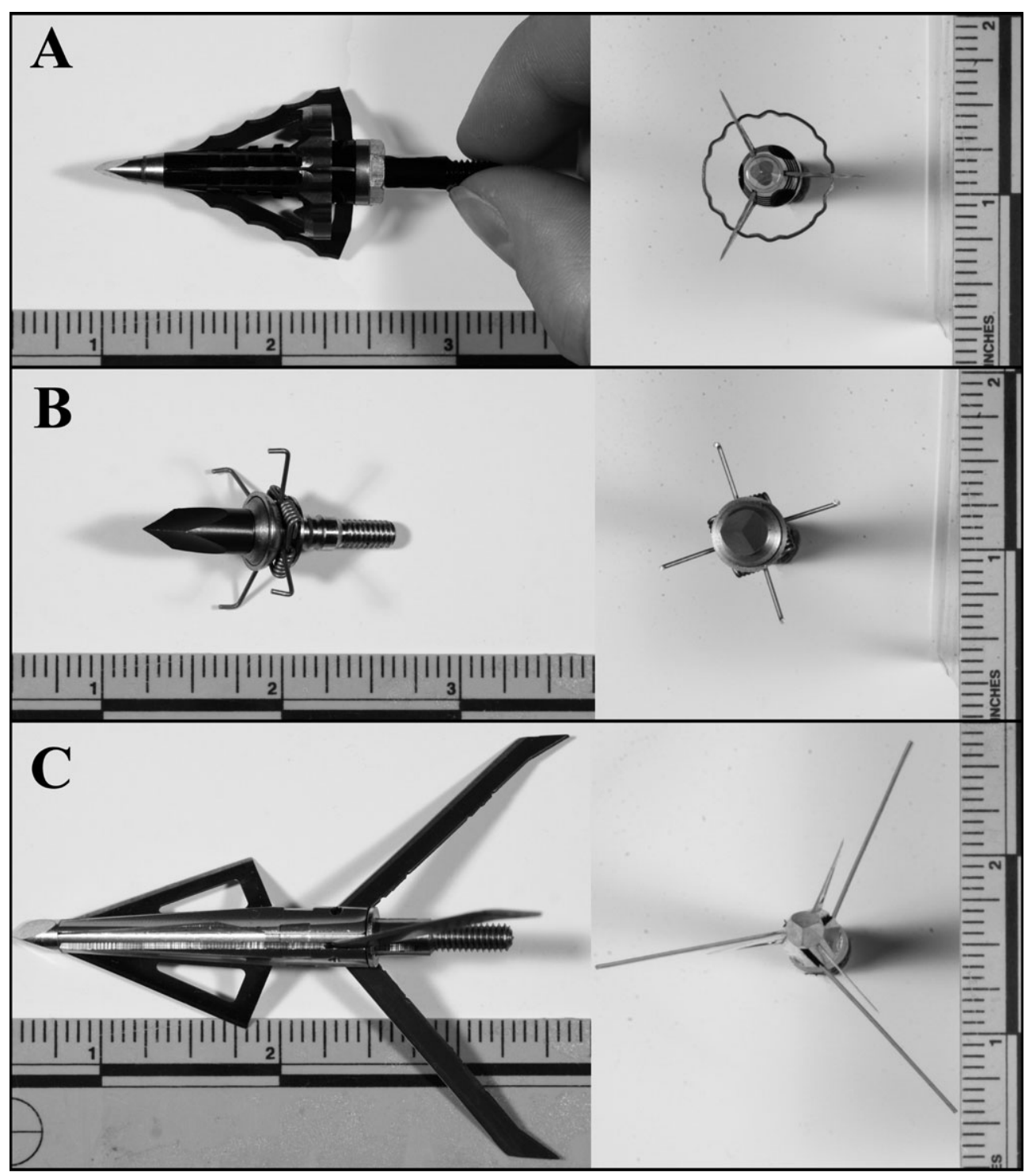

FIG. 9-Additional variant broadheads, side and tip views: (A) Outdoor Sports Products ${ }^{\circledR}$ SaberMaxx ${ }^{T M}$ (B) Muzzy ${ }^{\circledR}$ small game point (C) Trophy Ridge ${ }^{\circledR}$ Buckblaster ${ }^{\text {TM }}$. Scale in inches.

possessing bilateral pointed ends (7). The length of the stab wound on the skin reflected the maximum width of the blades if the arrow shaft was perpendicular to the skin surface (Fig. 12A). These two broadheads had blades that were continuous with the tip and began cutting the skin immediately upon contact. This contrasts with those having trocar tips, like the Swhacker®, with wounds exhibiting central abrasion flanked by nonabraded cuts having bilateral pointed ends (Fig. 12B). The G5 ${ }^{\circledR}$ Havoc $^{\mathrm{TM}}$ and Rage ${ }^{\circledR}$ X-Treme ${ }^{\mathrm{TM}}$ are classified as two-blade broadheads, but have accessory cutting edges affixed to the tips that are oriented perpendicularly to the blades. These small cutting edges slice upon contact and help create a long, nonabraded stab wound with small, right-angled cuts at the center (Fig. 12C).

The G5 ${ }^{\circledR}$ Montec $^{\mathrm{TM}}$ represents a basic three-blade broadhead design. Its contiguous tip and blades cut on contact and leave a nonabraded, three-pointed star wound pattern where the length of the wound mimics the width of the blades (Fig. 13A). The Muzzy ${ }^{\circledR} \operatorname{Trocar}^{\mathrm{TM}}$ showed central abrasion with three, radiating, nonabraded cuts. The other three-blade arrowheads tested deviated from this type. The Grim Reaper ${ }^{\circledR}$ Razortip $^{\mathrm{TM}}$ and
Spitfire ${ }^{\circledR} \operatorname{Maxx}^{\mathrm{TM}}$ reflect a popular style of mechanical blade deployment where the blades fold backward upon penetration into the skin and expose their cutting edge as it continues through the target. Although the blades are razor sharp, both the central portions and three radiating cuts were abraded (Fig. 13B). The Rage ${ }^{\circledR}$ Kore $^{\mathrm{TM}}$ was unlike any of the other broadheads because of its unsharpened tip. The wound showed large perforations with extensive abrasion and radiating cuts (Fig. 13C).

The Magnus ${ }^{\circledR}$ Stinger Buzzcut ${ }^{\mathrm{TM}} 4$ blade cuts on impact and showed four, evenly distributed, nonabraded cuts. The four blades of the broadhead are oriented in a plus-shape with the two shorter blades being perpendicular to the longer ones. This design creates two-blade widths, and two different stab-wound lengths on the skin (Fig. 14).

The variant broadheads produced by Flying Arrow Archery ${ }^{\circledR}$ had similar designs, each possessing trocar tips and curved blades. The configuration of the blades for the Cyclone ${ }^{\mathrm{TM}}$ and Tom Bomb ${ }^{\mathrm{TM}}$ is similar with the only significant difference being the width of the blades and corresponding length of the wound 


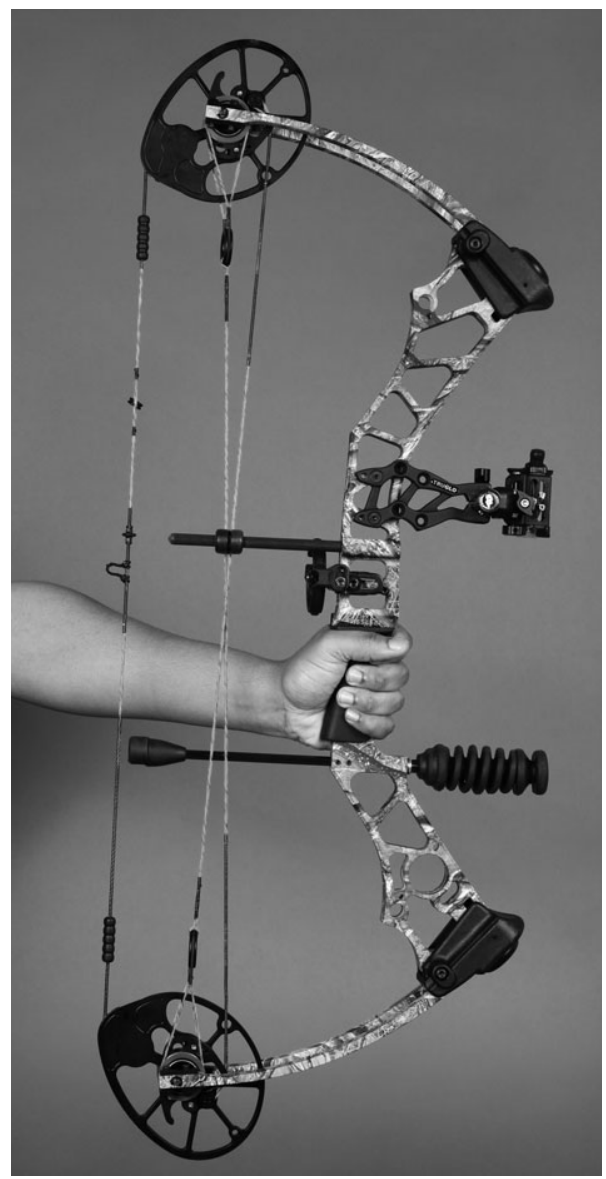

FIG. 10-Mission ${ }^{\circledR}$ Ballistic ${ }^{T M}$ compound bow.

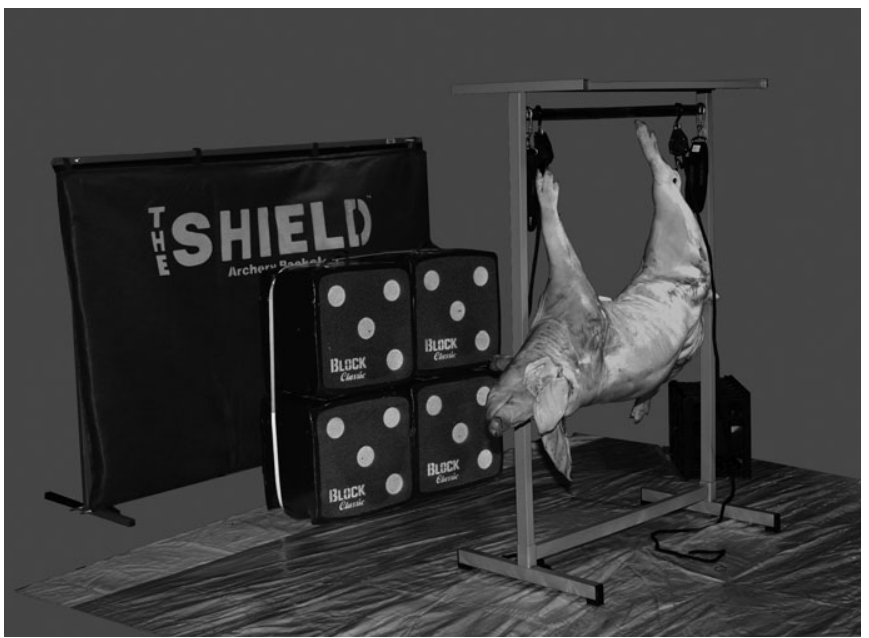

FIG. 11-Experiment setup.

created on the skin, where the Tom Bomb ${ }^{\mathrm{TM}}$ was 3.5 times greater than the Cyclone ${ }^{\mathrm{TM}}$ (Fig. 15A). The Toxic ${ }^{\mathrm{TM}}$ employs sixcurved blades that are paired and creates a symmetrical cloverleaf pattern on the skin (Fig. 15B). As with the other broadhead with trocar tips, these three arrowheads displayed abraded centers. The Trophy Ridge ${ }^{\circledR}$ Buckblaster ${ }^{\mathrm{TM}}$ had six straight blades, with one set of three blades only slightly offset from the other set of three, creating a $6.8 \mathrm{~cm}$ diameter, three-pointed star pattern with smaller cuts radiating from the center (Fig. 15C). The SaberMaxx $^{\mathrm{TM}}$ (Fig. 16A) produced the most dissimilar entrance wound with a $1.7 \mathrm{~cm}$ diameter hole and three $7 \mathrm{~mm}$ cuts spaced $120^{\circ}$ apart when shot perpendicular to the skin (Fig. 16B). If penetration is oblique to the skin surface, the serrations of the central ring of this broadhead are clearly imparted at the cut edge (Fig. 16C). The tissue core carved by the circular blade was drawn into the wound track.

Contrasting with the bladed broadheads, field points and small game points have no cutting blades. Their wounds displayed predominantly round holes, had central tissue destruction, lacked tissue edge re-approximation, and had minimal marginal abrasion (Fig. 17). These wounds closely mimicked entrance gunshot wounds.

The compound bow and arrow combination used in this experiment were able to propel many of the broadhead-affixed arrows completely through the thoracic cavity, creating both entrance and exit wounds. These perforating wounds were seen with the Carbon Express ${ }^{\circledR}$ Nativ $^{\mathrm{TM}}$, Magnus ${ }^{\circledR}$ Stinger $^{\mathrm{TM}} 2$ blade, Rage ${ }^{\circledR}$ X-Treme ${ }^{\mathrm{TM}}$, G5 ${ }^{\circledR}$ Montec $^{\mathrm{TM}}$, Muzzy ${ }^{\circledR}$ Trocar $^{\mathrm{TM}}, \mathrm{G}$, ${ }^{\circledR}$ $\mathrm{T}^{\mathrm{TM}}{ }^{\text {, Magnus }}{ }^{\circledR}$ Stinger Buzzcut ${ }^{\mathrm{TM}} 4$ blade, Flying Arrow Archery ${ }^{\circledR}$ Cyclone $^{\mathrm{TM}}$, and the Flying Arrow Archery ${ }^{\circledR}$ Toxic $^{\mathrm{TM}}$. Despite transecting ribs along its wound path, the exit wounds were nearly identical to the entrances. The plastic fletching of the arrows flexed and molded as they passed through the wounds and did not alter the morphology of the entrance or exit wounds (Fig. 18).

There was limited ability of the broadheads to penetrate the full thickness of the parietal skull. More frequently seen was that the arrowhead would strike the parietal bone, become deflected, and then travel through the soft tissue of the lateral cheek. The production of a small amount of metallic sparks was observed on two occasions when the skull was struck with the Rage ${ }^{\circledR} \mathrm{X}-$ Treme $^{\mathrm{TM}}$.

\section{Discussion}

There has been an appreciable spike in attendance at archery ranges and in people receiving and seeking archery lessons. A significant portion of this interest has been fomented by the popularity of juvenile and young adult literature and movies featuring protagonists skilled in archery. Studies commissioned by the Archery Trade Association indicated that almost 19 million people in the United States participated in archery, whether in the form of target shooting and/or bowhunting in 2012 (8), with an increase to 21.6 million in 2014 (9). With proper education and employment of safe practices, few injuries are attributed to the participation in archery. These minor injuries include lacerations and incised wounds from the mishandling of equipment, punctures, as well as minor contusions and abrasions (10).

Although rare compared to firearm deaths, there are periodic homicide cases in the United States involving the use of a bow and arrow (3). There are currently no manuscripts published on a large series of arrow injuries using different types of arrowheads, and the infrequency of these cases combined with unfamiliarity with this form of weaponry can make interpretation of wounds challenging for forensic pathologists. A complete investigation of death in these cases is simplified with the retention of the projectile within the body, however, drawing from game hunting, current technology, and design allows many modern compound bows to propel broadhead-tipped arrows through thoracic and abdominal cavities with ease and leave only a wound track (4). Arrowhead injuries, in the absence of the projectile or 


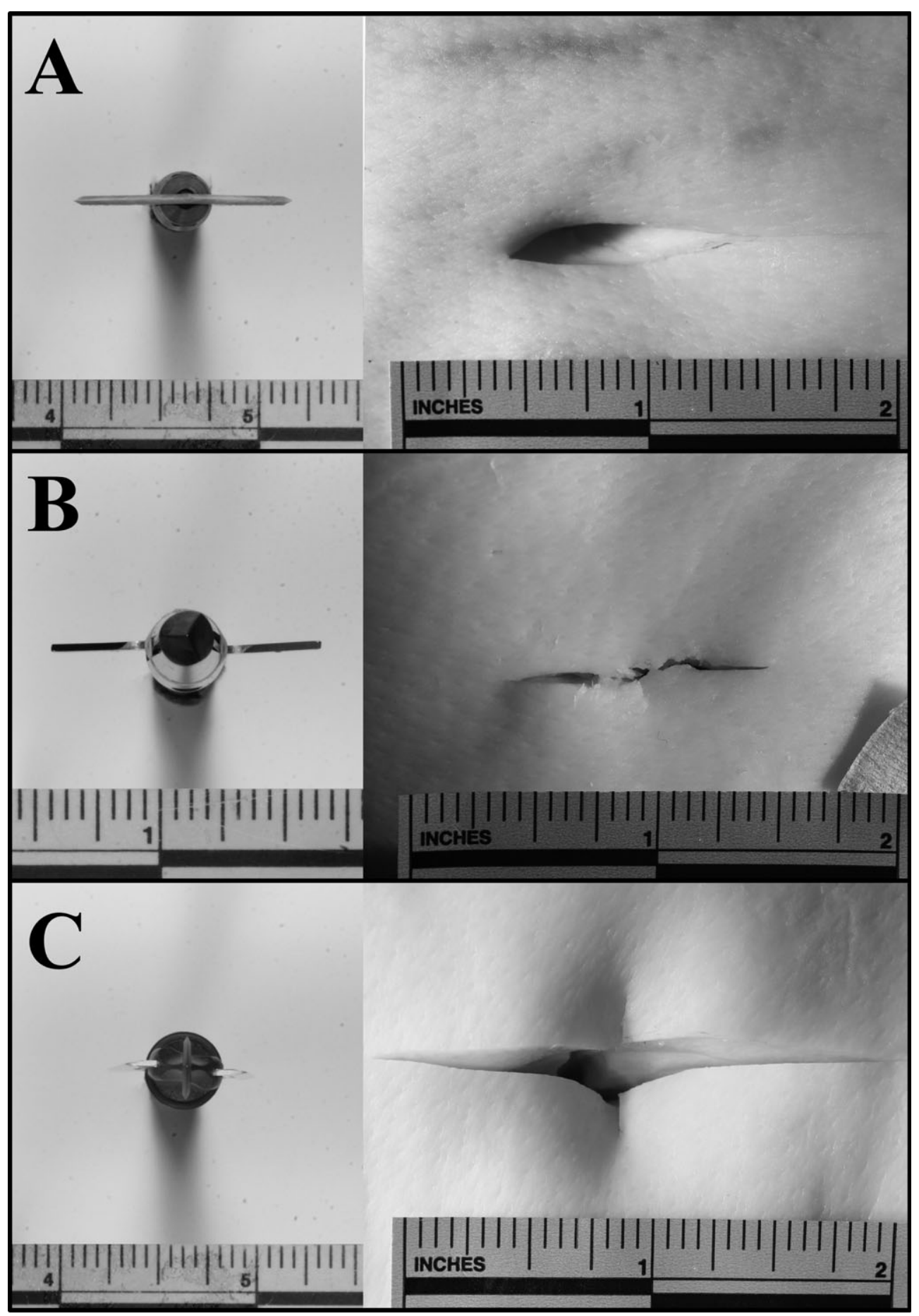

FIG 12-Examples of two-blade arrowhead wounds: (A) Magnus ${ }^{\circledR}$ Stinger $^{T M} 2$ blade (B) Swhacker ${ }^{\circledR}(C)$ G5 ${ }^{\circledR}$ Havoc ${ }^{T M}$. Scale in inches.

available history, can mimic injuries caused by other instruments that cause penetrating wounds.

Entrance wounds created by fixed, two-blade arrowheads that cut upon contact with the skin, such as the Carbon Express ${ }^{\circledR}$ Nativ $^{\mathrm{TM}}$ and Magnus ${ }^{\circledR}$ Stinger $^{\mathrm{TM}}$, are similar to those inflicted by traditional sharp instruments, such as a knife blade (7). When the arrowhead enters perpendicular to the skin, the created injury is a stab wound, where the length of the cutaneous injury is less than the depth of internal damage. With tangential contact with the skin, the arrowhead creates a typical incised wound by cleaving a lengthy, shallow path across the skin. A combined, stab-incised wound is seen when the arrow enters the skin at an angle.

In contrast, broadheads with trocar tips manifested discernibly different wound morphology than the cut-on-contact variety. Although the trocar tip is sharpened and is able to pierce the skin, it lacks the ability to cleanly cleave the skin. The injuries reproducibly displayed abrasion of the central portion of the wound flanked by nonabraded incised wounds. The observed results are in opposition to previously reported findings (3).

Some broadheads are classified as two-blade arrowheads but possess blades placed perpendicularly to the main blades. The 


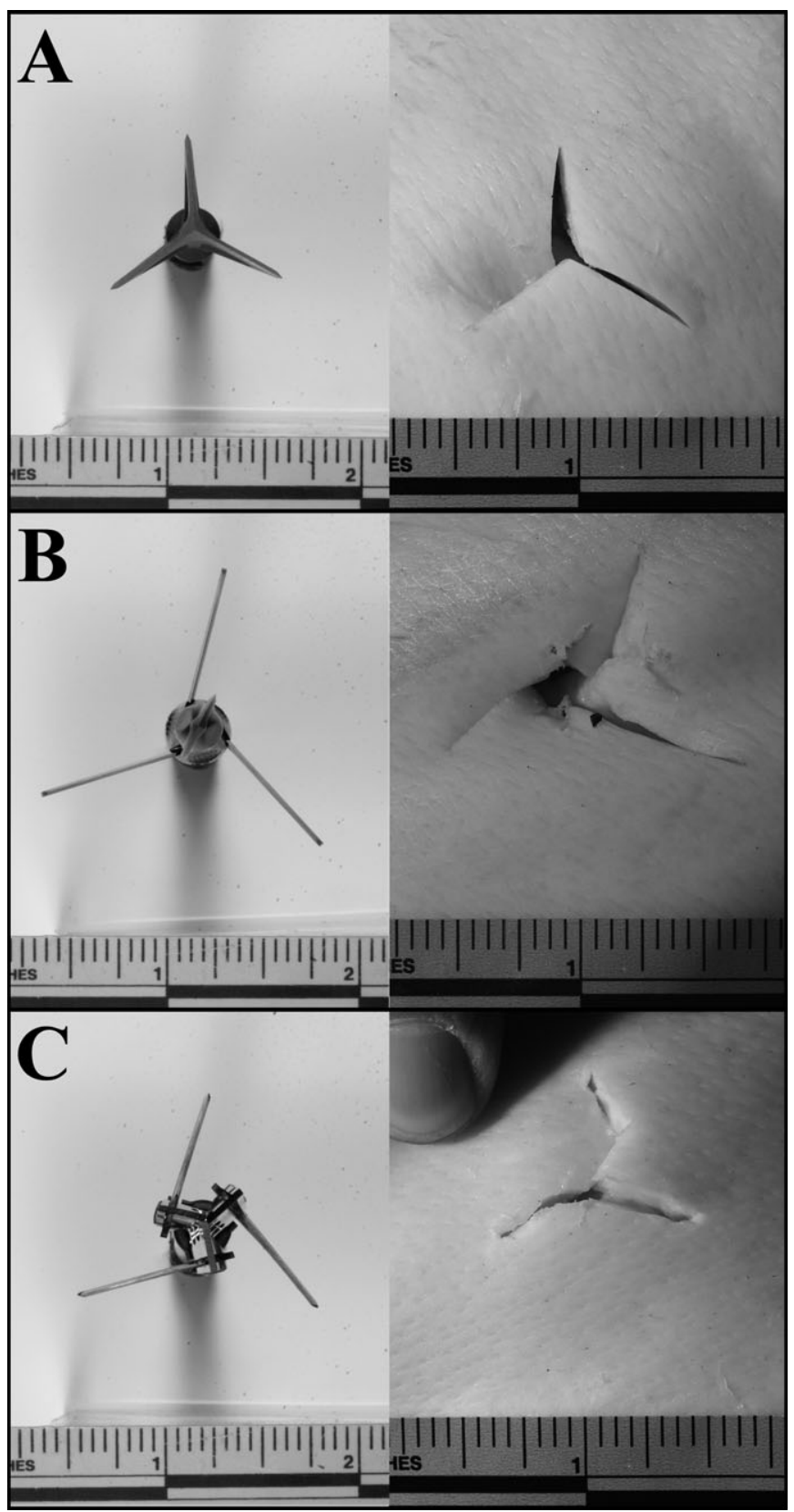

FIG. 13-Examples of three-blade arrowhead wounds: (A) G5® Montec ${ }^{\text {TM }}$ (B) Spitfire ${ }^{\circledR} \operatorname{Maxx}^{T M}(C)$ Rage ${ }^{\circledR}$ Kore $^{T M}$. Scale in inches.

created wounds are cross-shaped and mimic those created by the four-blade arrowhead.

As with two-blade broadheads, the three-bladed varieties are also able to create stab, incised, and stab-incised wounds, but with three cuts radiating from a central axis. Assessment of the cutaneous wounds requires reapproximation of the wound edges because the blades necessarily transect some skin cleavage lines (Langer's lines) and may be under tension. Broadheads not having a cut-on-contact design, such as those with trocar tips or mechanical deployment, displayed central abrasion. The most distinct example of this was seen with the Rage ${ }^{\circledR}$ Kore $^{\mathrm{TM}}$, a mechanical broadhead with no sharpened blades. The compound bow propelled the nonsharpened broadhead with sufficient force to perforate the skin, and the blunt blades abraded the skin as it entered.

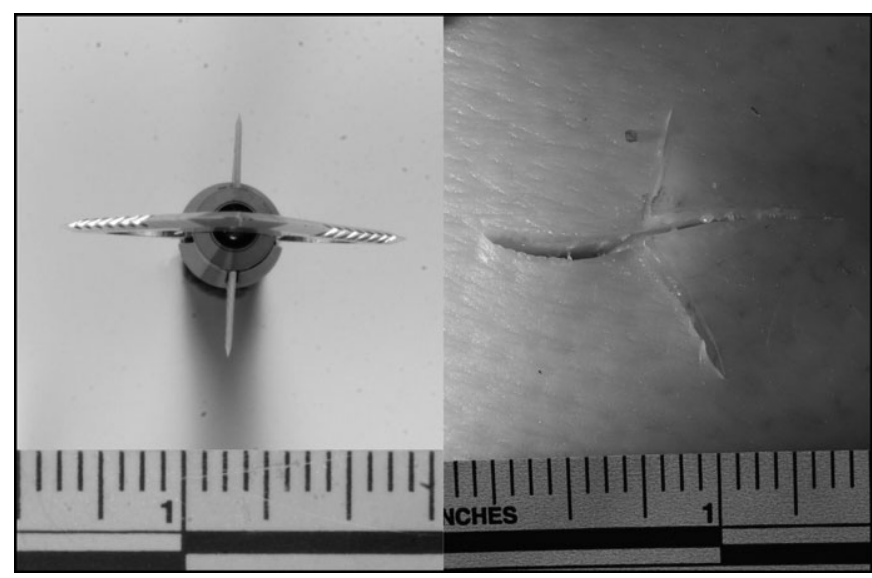

FIG. 14-Example of Magnus ${ }^{\circledR}$ Stinger Buzzcut ${ }^{T M}$ four-blade arrowhead wound. Scale in inches

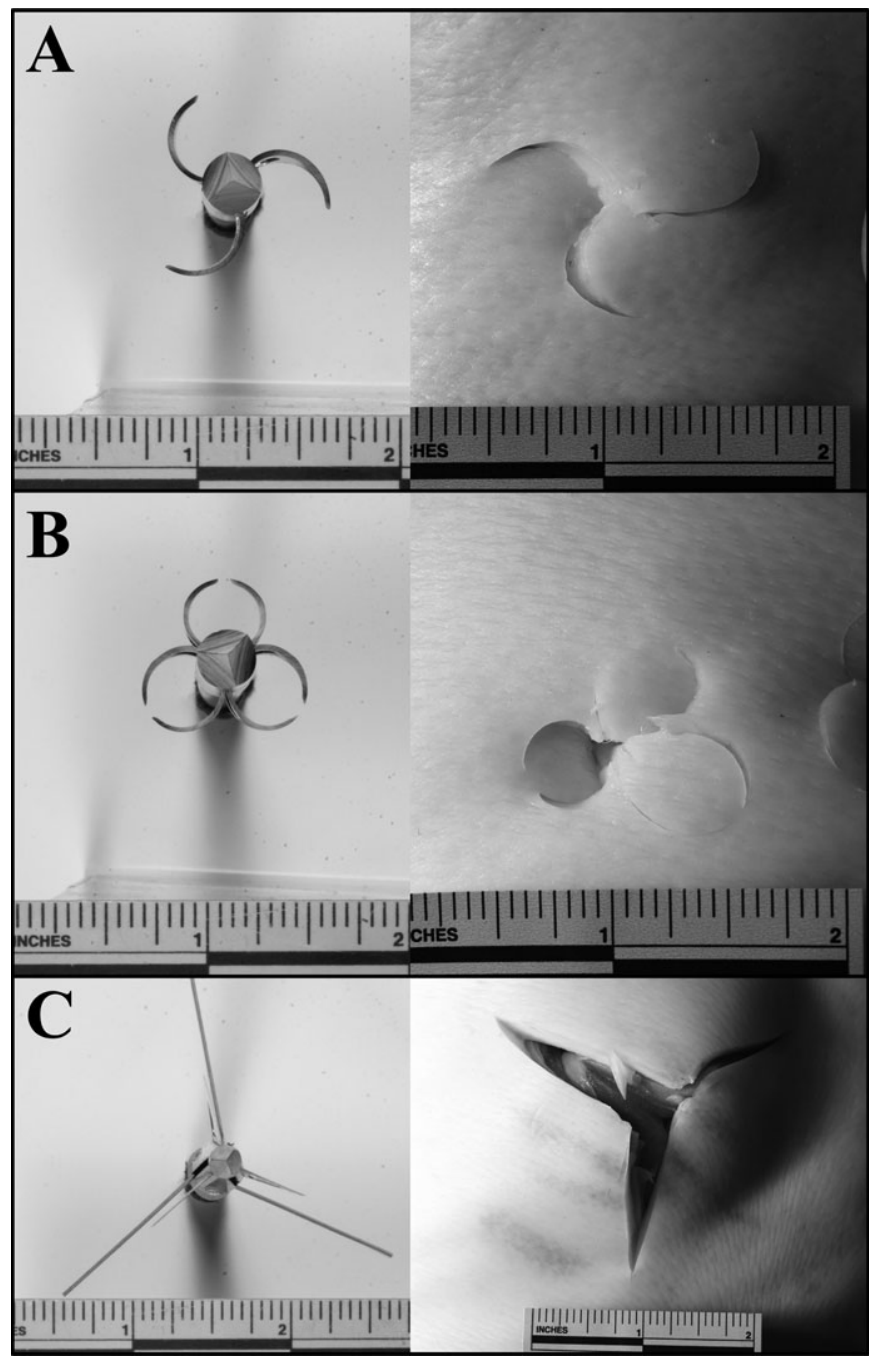

FIG. 15-Examples of variant arrowhead wounds: (A) Flying Arrow Archery ${ }^{\circledR}$ Cyclone $^{T M}\left(\right.$ B) Flying Arrow Archery ${ }^{\circledR}$ Toxic $^{T M}$ (C) Trophy Ridge ${ }^{\circledR}$ Buckblaster $^{T M}$. Scale in inches.

Only one-four-blade arrowhead was tested in this study. This created a cross-shaped stab wound and mirrored the appearance of the broadhead. Although no trocar-tipped or mechanical, 


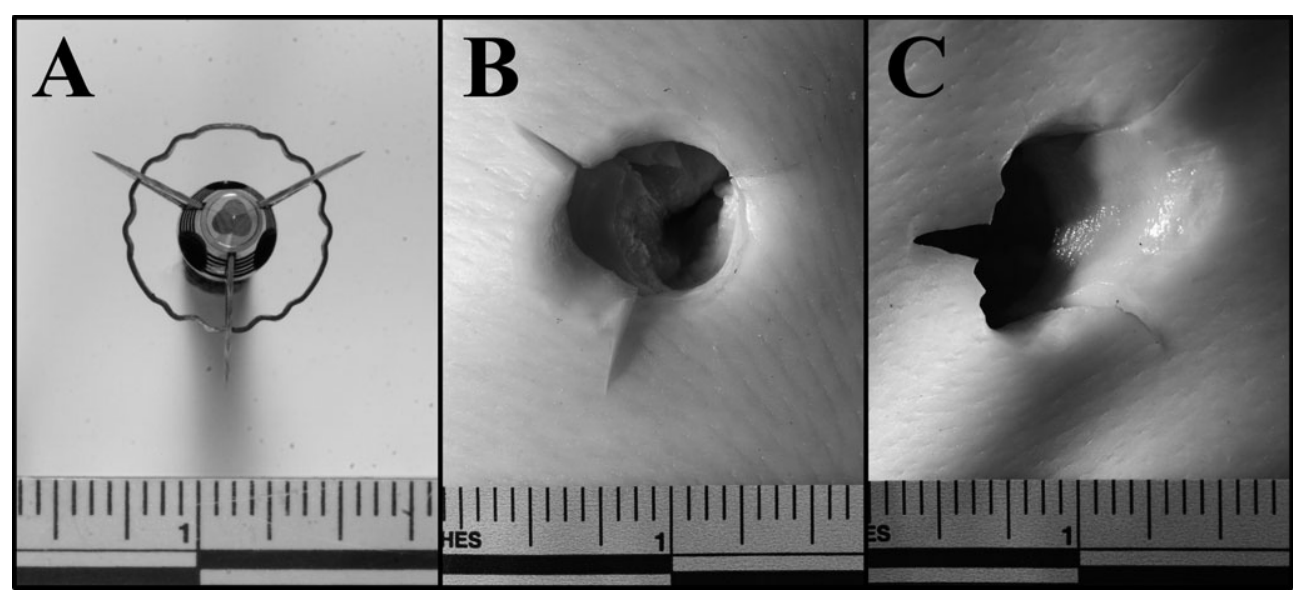

FIG. 16-Wound from Outdoor Sports Products ${ }^{\circledR}$ SaberMaxx ${ }^{T M}$ broadhead. Scale in inches: (A) Broadhead (B) Perpendicular entrance wound (C) Tangential entrance wound. Scale in inches.

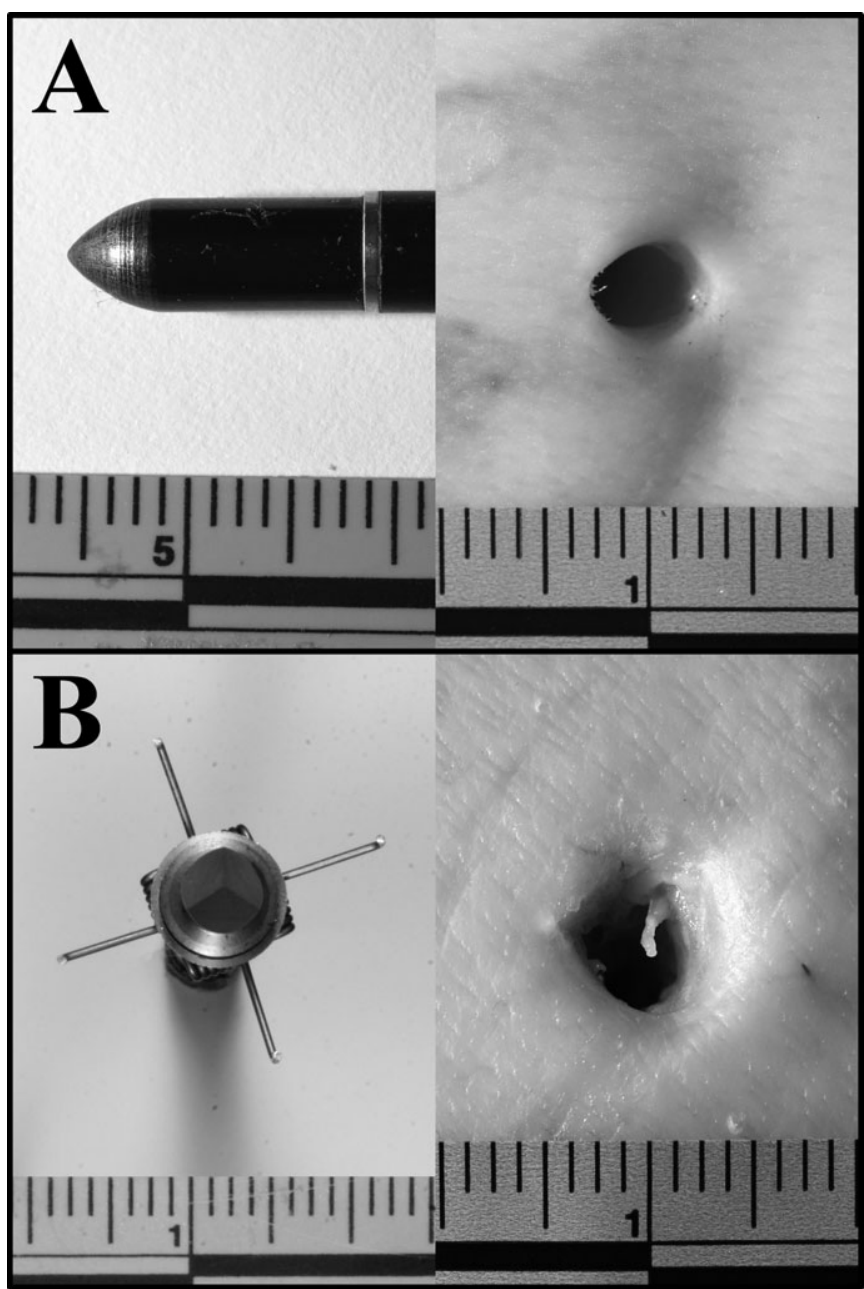

FIG. 17-Examples of Entrance gunshot wound mimics: (A) Field tip (B) Muzzy® small game point. Scale in inches.

four-blade broadheads were tested, it is likely that they would also display abraded central points similar to the two-blade and three-blade varieties.

Five variant broadheads were chosen for comparison with the traditional arrowheads. Three of the variants, the Flying Arrow Archery ${ }^{\circledR}$ Cyclone $^{\mathrm{TM}}$, Tom Bomb ${ }^{\mathrm{TM}}$, and $\mathrm{Toxic}^{\mathrm{TM}}$, possessed

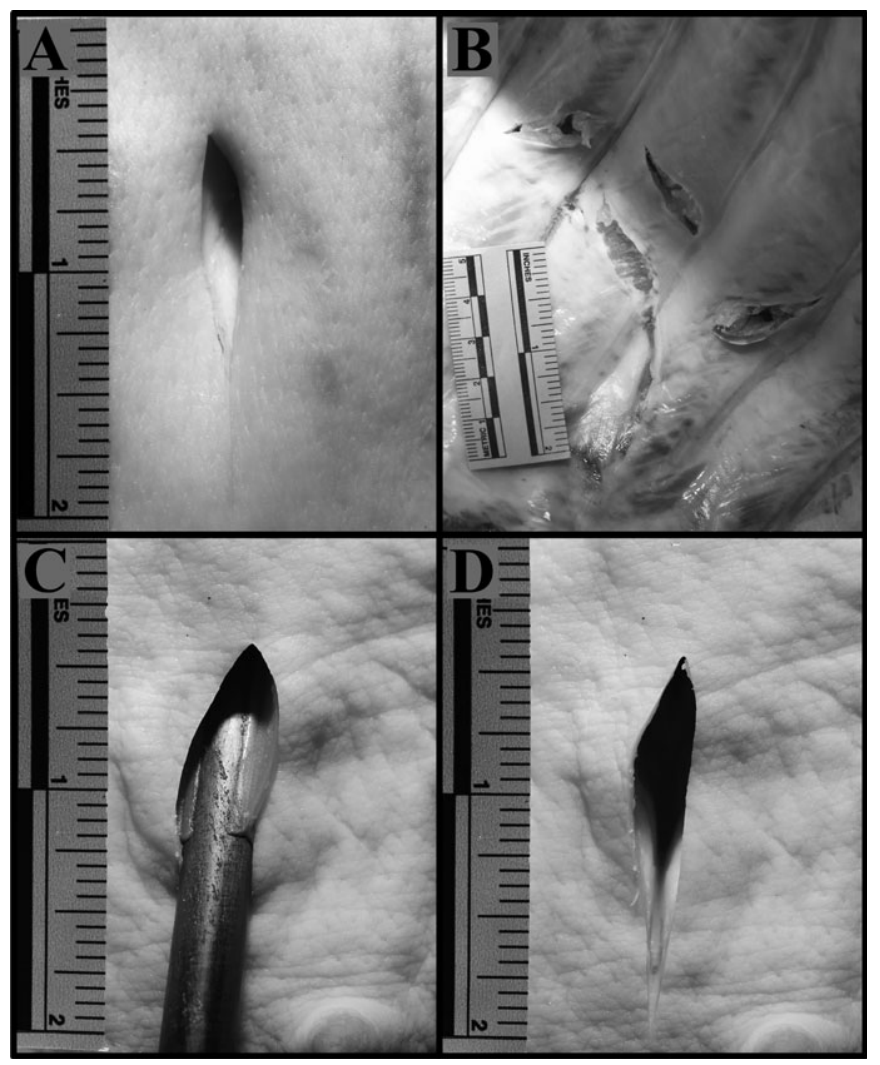

FIG. 18-Arrow passing through thoracic cavity: (A) Entrance wound (B) Transection of ribs (C) Arrow fletching passing through exit wound (D) Exit wound. Scale in inches.

curved blades and formed wounds that corresponded to their rounded-shape and lacked major distortion from the Langer's lines. The arcs of the blades transect the skin's cleavage lines in two places, reducing the tension and the amount the wound edges were pulled apart.

The Trophy Ridge ${ }^{\circledR}$ Buckblaster ${ }^{\mathrm{TM}}$, the fourth variant arrowhead studied, consisted of both a three-blade fixed broadhead in conjunction with a three-blade mechanical design. While there were a total of six cutting edges that produced a large, $6.8 \mathrm{~cm}$ diameter wound, one set of three blades were only slightly offset from the other three, creating a wound that 
was very close in appearance to a standard three-blade broadhead.

The entrance wound and wound track of the fifth broadhead, the SaberMaxx ${ }^{\mathrm{TM}}$, contrasted the greatest from the other broadheads. Its circular blade removed a core of skin and tissue with a diameter nearly equivalent to the bore of a 16-gauge shotgun. Although lacking marginal abrasion and possessing three equally spaced cuts at the periphery, the entrance wound from this broadhead may be mistaken for that of a shotgun wound if hastily examined. If entering the skin at an angle, the serrations of the circular blade produced sinusoidal oscillations of regular periodicity, which may be mistaken for scalloping from shotgun pellet separation (11).

Included in this study were small game points and field points. These two styles are used exclusively for hunting small game, such as squirrels and rabbits, and target shooting, respectively. They have no cutting edges and produce marginal abrasion upon penetration through skin. The circular hole with its circumferential abrasion and lack of tissue edge reapproximation, mimicked a typical, distant, gunshot entrance wound $(12,13)$.

Accurate description of the wound path produced by an arrow is complicated when the projectile completely passes through the body. While typical gunshot wounds lend themselves to easier wound path determination because of the difference in appearance of the entrance and exit wounds, the same cannot be said of arrowhead injuries. Using the same criteria of the blades and arrows, the arrow entrance and exit wounds were identical even after the broadheads transected multiple ribs as it passed through the target. This was true of the arrow fletching also. The flexible construction of the fletching allowed them to bend within the wound path and not impart any distortions.

Although there are many more broadheads than the subset tested in this study, the ones selected represent the major classes that are commercially available. Review of these injuries can provide forensic pathologists with a greater understanding of a type of stab wound not frequently encountered.

\section{Limitations}

The study was performed on animal carcasses that lack active circulatory systems. It is acknowledged that documentation of vital reactions from inflicted injuries provides useful data; however, it was felt that sufficient information could be gathered without using live animals. The carcasses also were absent of internal organs, and evaluation of visceral injuries was not performed. Due to the United States Department of Agriculture (USDA) regulations on the sale of animal carcasses, animals with intact internal organs slaughtered immediately prior to experimentation could not easily be obtained.

As for the performance of the experiment, the carcasses were refrigerated and kept at a low temperature prior to shooting. There is no argument that the temperature of tissue alters its rigidity, pliability, and resistance to penetration. The carcasses were not raised to standard body temperature; however, it is unlikely that the change in tissue temperature would have greatly altered the cutaneous wound morphology.

\section{Acknowledgments}

Special thanks and appreciation are extended to Dave Malosh. This project would not have been possible without his efforts in providing and preparing an area to perform the experimentation.

\section{References}

1. Grayson C, French M, O'Brien M. A brief overview of traditional archery. Traditional archery from six continents: the Charles E. Grayson collection. Columbia, MO: University of Missouri Press, 2007;1-10.

2. Fox ET, editor. Military archery in the seventeenth century. United Kingdom: Fox Historical Publications, 2015.

3. Eriksson A, Georén B, Öström M. Work-place homicide by bow and arrow. J Forensic Sci 2000;45(4):911-6.

4. Morton R, Guynn D Jr, Hortman R, Williams J. Efficiency of archery hunting for white-tailed deer on Medway Plantation. Proceedings of the Forty-Ninth Annual Conference Southeastern Association of Fish and Wildlife Agencies; 1995 Sep 23-27; Nashville, TN. Jackson, MS: Southeastern Association of Fish and Wildlife Agencies, 1995;432-8.

5. Karger B, Sudhues H, Kneubuehl BP, Brinkmann B. Experimental arrow wounds: ballistics and traumatology. J Trauma 1998;45(3):495-501.

6. Debeer S, Le Luduec JB, Kaiserlain D, Laurent P, Nicolas JF, Dubois B, et al. Comparative histology and immunohistochemistry of porcine versus human skin. Eur J Dermatol 2013;23(4):456-66.

7. DiMaio V, DiMaio D. Wounds caused by pointed and sharp-edged weapons. In: Forensic pathology, 2nd edn. Boca Raton, FL: CRC Press, 2001;187-228.

8. Responsive Management National Office. Archery participation among adult United States residents in 2012. Harrisonburg, VA: Archery Trade Association, 2013.

9. Responsive Management National Office. Archery participation among adult United States residents in 2014. Harrisonburg, VA: Archery Trade Association, 2015.

10. Palsbo S. Epidemiology of recreational archery injuries: implications for archery ranges and injury prevention. J Sports Med Phys Fitness 2012;52 (3):293-9.

11. DiMaio V. Wounds from shotguns. In: Gunshot wounds practical aspects of firearms, ballistics, and forensic techniques, 3rd edn. Boca Raton, FL: CRC Press, 2016;179-224.

12. DiMaio V. An introduction to the classification of gunshot wounds. In: Gunshot wounds practical aspects of firearms, ballistics, and forensic techniques, 3rd edn. Boca Raton, FL: CRC Press, 2016;57-108.

13. Grellner W, Buhmann D, Giese A, Gehrke G, Koops E, Püschel K. Fatal and non-fatal injuries caused by crossbows. Forensic Sci Int 2004;142 (1): 17-23.

Additional information and reprint requests:

LokMan Sung, M.D.

Department of Pathology

University of Michigan

Ann Arbor

MI

E-mail: Lsung@waynecounty.com 